\title{
Effectiveness of Health Education With Peer Education Method On The Attitude Of Student Bse (Breast Self-Examination) In Senior High School 5 Kediri
}

\author{
Suci Anggraeni, Cahyu Novita Angraeni \\ STIKes Surya Mitra Husada Kediri, East Java, Indonesia \\ Corresponding author: sucianggraeni87@gmail.com
}

\begin{abstract}
Background: BSE (Breast Self-Examination) is one of the early detection steps to prevent breast cancer is more effective if done as early as possible when adolescents reach the age of reproduction.

Purpose : The purpose of this research is to know the influence of health education with peer education method toward student attitude in do realize in Senior High School 5 Kediri.

Methods :The research design in this research is pre experimental design with one group pre test approach - post test design. The Sampel is some female students of class XI in Senior High School 5 Kediri as many as 104 respondents taken with Simple Random Sampling technique. Variable dependent attitude of student, independent variable of health education with peer education method. The instrument used is a questionnaire. The results of analysis using Mc Nemar with $\alpha=0,05$.

Result : The result of this research is that most respondents have positive attitude in doing BSE before giving health education as much 65 respondent $(62,5 \%)$, while most of respondent have positive attitude in doing BSE after giving health education 96 responden $(92,3 \%)$. The result of Mc Nemar statistic test is obtained $\rho$ value $=0,000<\alpha=(0,05)$, which means there is Effect of Health Education with Peer Education Method toward Student Attitudes In Conduct BSE in Senior High School 5 Kediri City.

Conclusion : Peer education method has relationship with respondent attitude about BSE because counseling with peer education method about is very important for respondent and expected by giving counseling about BSE will increase knowledge and also ability to do BSE for early detection breast cancer.
\end{abstract}

Keywords: Attitude, BSE (Breast Self-Examination), Peer Education, Student.

Received: January 12, 2019; Revised : February 24, 2019; Accepted March 14, 2019

How to Cite: Anggraeni, S., \& Angraeni, C.N. (2019). Effectiveness of Health Education With Peer Education Method On The Attitude Of Student Bse (Breast Self-Examination) In Senior High School 5 Kediri. Journal Of Nursing Practice. 2(2). 136-142. https://doi.org/10.30994/jnp.v2i2.57 


\section{INTRODUCTION}

Realize is the easiest and most important check for health. Nearly more than $50 \%$ of women don't realize, especially in adolescents only $20 \%$ to $30 \%$ are aware. This causes that a teenager is more susceptible to breast cancer. So that breast cancer is currently still the biggest problem in Indonesia. Morbidity and mortality rates tend to increase. Moreover, most of the sufferers were found in an advanced stage, so that prevention efforts were difficult to do well (Kartikawati, 2013). A person's behavior to carry out breast selfexamination is basically different. This is influenced by someone's knowledge about BSE is not good (Permatasari, 2015).

One of these breast cancer is hereditary disease 5\% of family history. So it is necessary to carry out early detection of breast cancer which plays an important role in anticipating the spread of breast cancer. With the early detection, the emergence of cancer cells can be immediately overcome and prevented. At present it is known that around $70 \%$ of many cancer patients who are late have not been detected, so that new patients who come to the doctor at high stage, consequently the risk of death from cancer is higher (Suryati and Purwoastuti, 2015).

Along with the times, the number of breast cancer in Indonesia continues to grow. At first breast cancer attacks women who are over 30 years old but, now breast cancer sufferers attack young or teenage women (Fres, 2015). This happened because the young women had never gotten the knowledge or education about the ways to do breast self examination.

At present in Indonesia there are estimated to be 100 breast cancer sufferers with 100,000 residents. This means that of the 237 million population there are around 237,000 new cancer sufferers. The prevalence of breast cancer in East Java in 2014 and 2015 was $0.03 \%$ and $0.05 \%$, whereas in 2016 the prevalence of breast cancer continued to increase by $0.06 \%$ and predicted until 2017 it continued to increase by $0.07 \%(\mathrm{MOH}, 2016)$.

Based on the data obtained from the City Health Office of Kediri, there were 43,586 women aged 30 - 49 years. The number of IVA (cervical) and breast cancer examinations was 1,600 , so the prevalence of breast cancer patients was $0.31 \%$. This shows that education about health education checks is less applied.

From the results of interviews conducted on August 19, 2017, found in one school there were a small number of 5 young women said that there was pain in her breasts and there were lumps and even 3 among the young women said sometimes the pain could not be tolerated. A small percentage of the 8 young women from 35 teenage girls had a good level of knowledge about breast images, but the overall number of young women today regarding attitudes and behaviors about breast self-examination is not good. This happened because the teenagers had never received information or education about breast selfexamination. So that until now health education with the peer education method of student attitudes in doing so has never been implemented.

Given the above problems, BSE is one of the steps to early detection to prevent breast cancer which is more effective if done as early as possible when adolescents reach reproductive age. BSE is considered the cheapest, safest, simplest way. With breast selfexamination it is not impossible that more early stage breast cancer can be detected. But, BSE is still considered ineffective. This is due to fear and anxiety in the face of reality, and there are still a few teenagers who use this method.

Besides that, the understanding of BSE is technically still not mastered. Not only that, the breast self-examination technique is also still common among young women, because there are still a small number of women who routinely carry out breast self-examinations every month (Hidayati, 2015). Breast self-examination efforts are very important because 
about $75-85 \%$ of breast cancer disorders are found when breast self-examination is done (Suyati and Purwoastuti, 2013). If the process of early detection of breast cancer is not done then it will not know how the breast is normally seen and cannot feel something (lump or mass) so that the young women are not ready if at one time they find a change that is a lump in their breasts.

Notoatmojo (2015) explains that the behavior of a young person or student about health is determined by knowledge, attitudes, beliefs, and traditions. There is still a lack of awareness of women - women in Indonesia in conducting early detection of breast cancer, even still many women do not know the ways - ways of early detection of breast cancer is quite large (Permatasari, 2015).

This is where the role of health workers is needed to improve the attitudes of adolescents need to be improved by providing health education as an effort to prevent the occurrence of cancer patyudara and teach early detection of breast cancer that is by way of breast self-examination. BSE should be done before bathing regularly. Performed at 7 to 10 days after menstruation, when breast swelling and pain has subsided. For beginners, health education can be carried out with peer education.

Based on the above phenomena, researchers are interested in conducting research on "The Effect of Health Education with the Peer Education Method on Students' Attitudes in Doing Awareness in SMAN 5 Kediri".

The purpose of this study was to determine the effect of health education with the peer education method on students' attitudes to realize in SMAN 5 Kediri.

\section{RESEARCH METHODS}

This research is a quantitative study using a pre-experimental design with a one group pre test - post test design approach. In this study the population used was all female students of class XI who were respondents as many as 142 respondents in SMAN 5 Kediri. Independent variable is health education using the peer education method. The dependent variable is the attitude of students.

The number of samples of this study were 104 respondents with sampling techniques using Simple Random Sampling. Data analysis using Mc Nemar test.

\section{RESULT}

Characteristics of respondents

\begin{tabular}{|c|c|c|c|c|}
\hline No & Characteristics & Category & $\mathrm{F}$ & $\%$ \\
\hline \multirow{3}{*}{1} & \multirow{3}{*}{ Age } & 16 years & 59 & $56,7 \%$ \\
\hline & & 17 years & 43 & $41,3 \%$ \\
\hline & & 18 years & 2 & $1,9 \%$ \\
\hline \multirow[t]{2}{*}{2} & \multirow[t]{2}{*}{ Information } & Ever & 72 & $69,2 \%$ \\
\hline & & Never & 32 & 30,8 \\
\hline \multirow{3}{*}{3} & \multirow{3}{*}{ Resources } & Internet & 42 & $40,4 \%$ \\
\hline & & Other people & 30 & $28,8 \%$ \\
\hline & & Never & 32 & $30,8 \%$ \\
\hline \multirow{2}{*}{4} & \multirow{2}{*}{ Examination } & Ever & 60 & $57,7 \%$ \\
\hline & & Never & 44 & $42,3 \%$ \\
\hline \multirow{2}{*}{5} & \multirow{2}{*}{ Family history } & Yes & 23 & $22,1 \%$ \\
\hline & & No & 81 & $77,9 \%$ \\
\hline
\end{tabular}


Most of them are 16 years with 59 respondents (57\%). Most respondents had received information about $\mathrm{BSE}$ as many as 72 respondents (69\%). Most of them got information about BSE from 42 Social Media (Internet) respondents (46\%). Most of the respondents had examined breast as many as 60 respondents (95\%). Most of the respondents' families did not have a history of 81 breast cancer $(88 \%)$.

Tabel 1 Frequency Distribution Variables Student Attitudes Before being given health education at SMAN 5 Kota Kediri

\begin{tabular}{cccc}
\hline No & $\begin{array}{c}\text { Attitudes of Students Before } \\
\text { Health education }\end{array}$ & F & $\%$ \\
\hline 1. & Positive & 65 & 62,5 \\
\hline 2. & Negative & 39 & 37,5 \\
\hline & Jumlah & 104 & 100 \\
\hline
\end{tabular}

Based on table 1, it is known that out of 104 respondents (100\%) respondents who had a positive attitude in doing BSE before being given health education were 65 respondents $(62.5 \%)$.

Tabel 2. Frequency distribution Variables Student Attitudes After being given health education at SMAN 5 Kota Kediri

\begin{tabular}{cccc}
\hline No. & $\begin{array}{c}\text { Student Attitudes After being } \\
\text { given Health Education }\end{array}$ & F & $\%$ \\
\hline 1. & Positifve & 96 & 92,3 \\
\hline 2. & Negative & 8 & 7,7 \\
\hline & Jumlah & 104 & 100 \\
\hline
\end{tabular}

Based on table 2, it is known that out of 104 respondents (100\%) most respondents had a positive attitude in doing BSE after being given health education by 96 respondents $(92.3 \%)$.

\section{Data analysis}

Based on the results of the analysis carried out using the Mc Nemar test to 104 respondents on March 26, 2018 it was found that $\rho$ value $=0,000$ with $\alpha=0.05$. Because the value of $\rho$ value $=0,000<0,05$, which means that there is an Effect of Health Education Effectiveness with the Peer Education Method on Student Attitudes in Conducting BSE at SMAN 5 Kota Kediri.

\section{DISCUSSION}

Students' Attitudes in Conducting BSE Before Health Education was given with the Peer Education Method at SMAN 5 Kota Kediri

The results showed that most respondents in conducting BSE before being given health education had a positive attitude of 65 respondents $(62.5 \%)$ and respondents who had negative attitudes were 39 respondents (37.5\%). Respondents have a positive attitude as respondents know after reaching the age of 40, BSE should be done every week, respondents will check with their doctor if they find a lump on their breast. 
Attitude is a form of evaluation / reaction to an object, impartial / impartial which is a certain order in terms of feelings (affection), thought (cognition) and predisposition of action (konasi) someone towards an aspect in the surrounding environment (Saifudin A, 2012). BSE is a manual breast examination manually. The purpose of this examination is to help women to detect early abnormalities in the breast (Suddarth \& Brunner, 2013).

The results of the study showed that most respondents in conducting BSE before being given health education had a positive attitude of 65 respondents $(62.5 \%)$ and respondents who had a negative attitude before being given health education were 39 respondents $(37.5 \%)$. This is supported by the theory that a certain attitude towards an object shows about people's knowledge of the object of the attitude in question (Wawan \& Dewi, 2011). The positive attitude that must be possessed by young women is to accept the method of BSE examination as early detection of breast cancer and carried out routinely. Receiving can be interpreted that subjects want and pay attention to given objects (Wawan \& Dewi, 2011). Negative attitude from the respondents because the respondents did not understand how to examine BSE. Respondents did not understand the function of the role of parents, especially the mother and a friend, and lack of interest in seeking information about reproductive health, especially how to examine BSE. Less knowledge will have an impact on negative attitudes because they do not know how to conduct BSE examination so interest in doing BSE examination is also reduced.

From the results of the study, it was found that the majority of respondents aged 16 years had a negative attitude before being given health education as many as 36 respondents (34.6\%). Research Handayani (2012), that respondents who are in the age range of 16-18 years or in the early adolescent phase as much as the majority (87.6\%) have never received information about how to conduct BSE, have less knowledge about how to do BSE. Where children do not know and get information about their reproductive health. Children also still do not think about reproductive health. They still think of fun and playing with their friends.

\section{Students' Attitudes in Conducting BSE Before Health Education was given with the Peer Education Method at SMAN 5 Kota Kediri}

The results showed that most respondents had a positive attitude in doing BSE after being given health education as many as 96 respondents $(92.3 \%)$ and students with negative attitudes after being given health education as many as 8 respondents $(7.7 \%)$. Respondents have a positive attitude as respondents know BSE is a breast self-examination every month, respondents will examine their doctor if they find a lump in the breast, respondents know breast cancer can be detected early with BSE, and respondents will always do BSE if there are complaints.

The success of counseling is inseparable from several factors such as those proposed by Fitriani (2011) that the factors that influence the success of an education include the target factors which include education level, socio-economic level, customs, public trust in the delivery of information and the lack of time. In addition there are other factors such as extension factors such as thorough preparation, mastery of material, convincing appearance, easy to understand language and voices that can be heard by respondents.

The results showed that most respondents had a positive attitude in doing BSE after being given health education as many as 96 respondents $(92.3 \%)$ and students with negative attitudes after being given health education as many as 8 respondents $(7.7 \%)$. Judging from the results of the study, there were many students in the category of positive attitudes. Although 96 students have a positive attitude, there are still 8 students who have 
a negative attitude. Personal experience is one of the factors that influence a person's attitude. Theory states that in order to be able to become the basis of attitude formation, personal experience must leave a strong impression. Mass media also influences a person's attitude because the news that should be factually conveyed objectively tends to be influenced by the attitude of the author, consequently it will affect the attitude of the consumers (Wawan \& Dewi, 2011). In addition to personal experience and mass media, there is a stage of motivation that changes a person after attending health education to truly change daily behavior (Susilo, 2011). Although there has been an increase in attitudes from students who have a negative attitude to be positive, there are still some students who have negative attitudes. This is because students are not optimally listening to counseling from researchers. Researchers have optimally delivered materials and materials in counseling about BSE. But sometimes there are still students who do not pay attention to the counseling. Negative attitudes of students can be caused by boredom when listening to counseling, the atmosphere of a hot place, interference from friends and more busy themselves to play gadgets rather than listening to counseling. Therefore students do not do BSE in accordance with good procedures.

After students are given counseling, they are aware of the importance of BSE starting early. Therefore students want to do BSE starting now.

\section{The Effect of Health Education with the Peer Education Method on Student Attitudes in Conducting BSE at SMAN 5 Kota Kediri}

Based on the results of statistical tests using Mc Nemar with an error rate of $\alpha<0.05$, the significant value of $\rho$ value $=0,000<0.05$ which means there is an Influence of Health Education with Peer Education Method on Student Attitudes in Examination at SMAN 5 Kota Kediri. It is known that respondents who had a positive attitude in doing BSE before being given health education were 65 respondents $(62.5 \%)$, while respondents had a positive attitude in doing BSE after being given health education by 96 respondents $(92.3 \%)$. It can be concluded that there was an increase of 31 respondents $(29.8 \%)$.

Health education is a process that bridges the gap between health information and health practices, which motivates someone to get information and do something so they can keep themselves healthier by avoiding bad habits and forming habits that benefit health (Notoatmodjo, 2015).

A teenager needs to know, understand and realize that carrying out breast selfexamination is very important for his health. Both understand from the understanding of breast self-examination, benefits and goals, and the consequences of not doing breast selfexamination (Nisman, 2011).

Behavior that is based on education and attitudes will be more lasting than those that are not based on education and attitude. Moreover, implementing health education for these students is supported by the existence of peer education methods, which means referring to various approaches such as communication channels, methodology, philosophy, and strategies, especially groups of adolescents categorized by age, class or status.

In the area of high school students 5 Kediri the coverage information about BSE is not good. They lack confidence to carry out breast self-examination and the level of knowledge and attitudes about BSE is still low, especially if those who teach BSE are their peers as well. Health education can improve women's knowledge and attitudes about breast cancer screening. This is because with the peer education method the respondents get information from the closest people who can become knowledge that forms a positive attitude. 
The reason for the peer education method has a relationship with the respondent's attitude about BSE because counseling with the peer education method about BSE is very important for the respondent and it is hoped that by giving counseling about BSE will increase knowledge and also the ability to conduct BSE for early detection breast cancer. With the knowledge and ability to conduct BSE indirectly will affect the attitude of respondents about BSE.

\section{CONCLUSION}

Most respondents who had a positive attitude in doing BSE before being given health education were 65 respondents $(62.5 \%)$.

Most of the respondents had a positive attitude in doing BSE after being given health education by 96 respondents $(92.3 \%)$.

There is the Effect of Health Education with the Peer Education Method on Students' Attitudes in Examination at SMAN 5 Kota Kediri with a value of $\rho$ value $=0,000$

\section{REFERENCES}

Azwar, Saifuddin. 2012. Sikap Manusia: Teori Dan Pengukurannya. Yogyakarta: Liberty. Brunner \& Suddarth. 2013. Keperawatan Medical-Bedah Edisi 12. Jakarta: EGC (Diakses

Tanggal 17 Oktober 2015 Jam 10.00 WIB)

Fres. 2015. Risiko Kanker Payudara Pada Remaja. Www.Sehatfresh.Com. Diakses

Tanggal 2 April 2016.

Hidayati. 2015. Pendidikan Kesehatan Melalui Metode Ceramah Dan Demontrasi Dalam

Meningkatkan Pengetahuan Tentang Kanker Payudara Dan Ketrampilan Praktik

Sadari Jurnal Kebidanan.Vol.1 No.1.

Http://Jurnal.Unimus.Ac.Id/Index.Php/Jur_Bid/Article/View.Com.

Info, Datin. 2016. Stop Kanker. Http://Www.Depkes.Go.Id/Resources/Pusdatin/.Com.

(Diakses Tanggal 2 April 2016)

Kartikawati, E. 2013. Awas!!! Bahaya Kanker Payudara \& Kanker Serviks. Bandung :

Buku Baru

Nisman, W, A. 2011. Lima Menit Kenali Payudara Anda. Yogyakarta: CV. Andi Offset

Notoatmodjo, S. 2015. Pendidikan Kesehatan Dan Perilaku Kesehatan. Jakarta : Rineka Cipta

Nurcahyo, J. 2010. Bahaya Kanker Rahim Dan Kanker Payudara. Yogyakarta : Wahana Totalita Publisher

Permatasari. (2015). Efektifitas Penyuluhan Sadari Terhadap Tingkat Pengetahuan Siswi

SMA Negeri Di Kecamatan Pontianak Barat. Jurnal Tanjung Pura Vol 1 No 1

Http://Jurnal.Untan.Ac.Id/Index.Php/Jfk/Article/View/3846. Diakses Tanggal 16

Oktober 2016 Jam 16.00 WIB.

Susilo, R. 2011. Pendidikan Kesehatan Dalam Keperawatan. Yogyakarta: Nuha Medika

Suyati, Purwoastuti. (2015). Kesehatan Reproduksi Buat Mahasiswa Kebidanan.

Yogyakarta : Nuha Medika.

Wawan \& Dewi M. 2011. Teori Dan Pengukuran Pengetahuan, Sikap, Dan Perilaku

Manusia. Cetakan II. Yogyakarta : Nuha Medika 